\title{
Brain Stem Astrocytoma
}

National Cancer Institute

\section{Source}

National Cancer Institute. Brain Stem Astrocytoma. NCI Thesaurus. Code C7445.

An astrocytoma that arises from the brain stem. 